\title{
The Differences of Taxpayer Compliance Before and After Tax Amnesty Stimulus
}

\author{
Subadriyah *) \\ Siti Aliyah **)
}

\begin{abstract}
Tax amnesty is a type of remission program for taxpayers where they are freed from their tax obligations but, in exchange for the tax liability forgiveness, have to pay a redemption amount of money and disclose incomplete or unreported income in their previous tax periods, without having to face theadministrative penalty or tax prosecution. The short-term purpose of tax amnesty is to increase the country's income in large quantities in a short time. In the long-term, this program is intended to form a wider database so that the government can increase the number of taxpayers and level of tax compliance. This study aims to determine the differences in taxpayer compliance during the periods before (pre-test) and after (pro-test) the Indonesian Tax Amnesty program which ended on March 31, 2017. The population was taken from the total data of taxpayers registered in KPP Pratama Jepara. The sample for this research includes 100 respondents based on Slovin's formula calculation. The sampling was done using purposive sampling, and the type of data used was primary data collected via questionnaire distribution. The method used for the data analysis was a paired sample t-test. The results showed that the taxpayer compliance between the pretest and protest of tax amnesty program changed. This difference indicates an increase in taxpayer compliance, although still very low.

Keywords: Tax Amnesty; Taxpayer Compliance

\section{INTRODUCTION}

\subsection{Research Background}
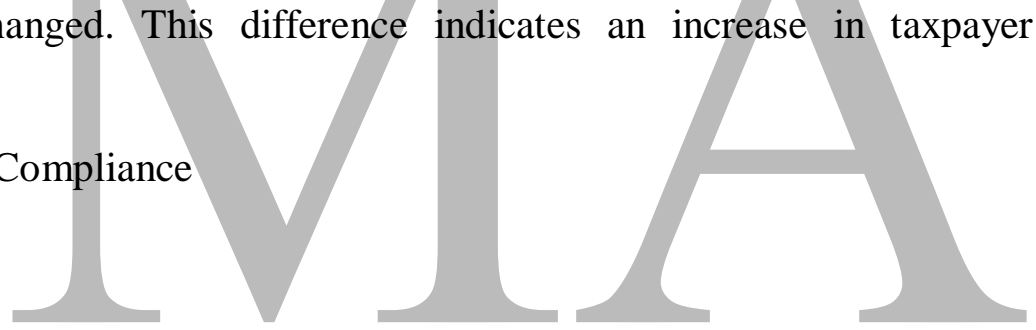

In Indonesia, tax continues to top the state's largest source of income. Until 2016, the tax still accounted for more than $75 \%$ of the state's revenues. However, the ratio of tax revenue in Indonesia is currently in the range of $13.2 \%$ (2015) and 14.2\% (2016). This ratio is still below the standards of ASEAN countries and the Organization on Economic Cooperation and Development. For comparison, the ratios of tax revenues in other countries are Germany $36.7 \%$, South Korea $24.3 \%$, UK 32.9\%, United States 25.4\%, Mexico 19.7\%, Japan 34.6\%, and China 19.4\%. Moreover, the level of taxpayer compliance in Indonesia is quite apprehensive and continues to decline; in 2011 it reached $97.2 \%$ but fell to $91.6 \%$ in 2014 , and again declined to only $82 \%$ in 2015 .

Level of tax compliance depends on the awareness of taxpayers in paying their taxes on time. In Indonesia, this awareness is still low, both in reporting tax returns and paying taxes. This condition naturally inhibits maximum state income. This sometimes happens due to taxpayers' lack of knowledge in carrying out their obligations instead of a deliberate evasion (Suyanto, Intansari, \& Endahjati, 2016). The lack of understanding that makes taxpayers fail to report their incomes and pay taxes can be categorized as passive tax evasion (Ayu \& Hastuti, 2009).

Taxpayers who already know and meet the provisions of the tax laws have no difficulty in performing their obligations. Individual employee taxpayers typically obtain Tax ID Numbers (NPWP) as a requirement before joining a company. Therefore they have to make tax reporting. Meanwhile, some corporate taxpayers may fail to pay their taxes because they obtain their NPWPs via credit application (Azwar \& Mulyawan, 2017). Based on the data on pajak.go.id, Indonesia's 
working population by 2015 consisted of 120.8 million people. However, the number of individual taxpayers (WP OP) who submitted their annual tax returns (SPT) was only 10,269,162 WP OPs, consisting of 837,228 non-employee WP OPs and 9,431,934 employee WP OPs. This indicates that the compliance level of WP OPs (seen from the submission of SPT) was only $40.75 \%$ (nonemployee WP OPs) and 63.22\% (employee WP OPs). What was more unfortunate was out of the total number of WP OPs who submitted their SPTs, only 794,418 WP OPs paid their taxes (Pajak, 2016).

This condition indicates that the potential of taxation in Indonesia is still very high, but not yet implemented optimally. To that end, the optimization of tax revenues needs to be done by the government for the sake of national development sustainability. Through the Directorate General of Taxation (DJP), the government continues to seek new breakthroughs to increase the tax revenue. One of the steps taken by the DJP in 2016 was the implementation of tax amnesty policy through Laws Regulation No. 11 of 2016. The amount of potential income that passes from the tax system is one factor that encourages many countries to implement a tax amnesty program to increase tax revenue without having to generate new tax burden. Furthermore, tax amnesty can withdraw funds in a short time from the redemption paid by amnesty participants, thus it is expected to encourage national development.

All taxpayers, both individual and corporate, may participate in the tax amnesty program, provided that they are not within the process of investigation and has obtained a P-21 (notification that the result of the investigation is complete) in the judicial process, or are serving a criminal penalty in tax. Taxpayers participating in this program will be exempt from any form of penalty when reporting assets that have not been reported in the past. The taxpayers will be subjected to:

a) a 2\% tax rate when delivering a statement within the first month up to the end of the third month (July 01-September 30, 2016) of their onshore assets or offshore assets that will be transferred to Indonesia, and $4 \%$ tax rate if the assets are not transferred to Indonesia;

b) a 3\% tax rate when delivering a statement within the fourth month up to the end of December 2016 (October 01 - December 31, 2016), of their onshore assets or offshore assets that will be transferred to Indonesia, and 6\% tax rate if the assets are not transferred to Indonesia; and

c) a 5\% tax rate when delivering a statement within January 1, 2017 to March 31, 2017, of their onshore assets or offshore assets that will be transferred to Indonesia, and $10 \%$ if the assets are not transferred to Indonesia (Tax Amnesty Law).

The redemption payment from the tax amnesty program proved to be a major contribution to the achievement of 2016 tax revenues. Of the total realization of tax receipts amounting to Rp1,105.97 trillion, the amount of the tax revenues from the amnesty during the 2nd period (until December 31, 2016) contributed Rp103.04 trillion (Dwijugiasteadi, 2016). Until the 3rd (final) period, the revenue achievement was only $81.8 \%$ of the targeted earnings (Ismi, 2017). However, compared to the tax amnesties in other countries, the achievement of Indonesia's amnesty that year was considered as one of the most successful. With a ratio of $0.83 \%$ of GDP, Indonesia's performance far surpassed other countries that were also running amnesty programs at that time. In terms of disclosure of property, Indonesia was also far superior compared to Italy (Rp59 trillion), Australia (Rp8 trillion), Chile (Rp20 trillion), and Spain (Rp18 trillion) (Pajak, 2016).

However, the success of amnesty cannot be measured only by the achievements of the disclosure of property and redemption payments. The long-term goal of the tax amnesty is the expansion of a more valid, comprehensive, and integrated database (Dwijugiasteadi, 2016). The program is expected to increase taxpayer compliance and tax revenue through on-going supervision (Andreoni, 1991). Tax amnesty will succeed in improving taxpayer compliance in the future through socialization and tax-aware campaigns in adequate media (Santoso \& Setiawan, 2009). 
Although in a federal state amnesties do not affect earnings significantly, they can be used as a tool to improve the taxation system (Lerman, 1986). Empirically, based on data from the United States between 1981 and 2011, it was found that amnesty programs were followed with the hope of obtaining forgiveness as well as future ease, thereby increasing taxpayer compliance (Bayer, Oberhofer, \& Winner, 2015). In addition, taxpayer compliance during tax amnesty periods is expected to increase, because with the remission program, the government managed to expand the taxpayer's database (Fatmala \& Ardini, 2017).

A research done in Bantul Regency in the Special Region of Yogyakarta showed the positive effect of tax amnesty on taxpayer compliance (Rahayu, 2017). This policy also positively affected the taxpayer compliance among the members of Islamic microfinance institution BMT (Baitul Mal Wat-Tamwil) in Pati Residency, Central Java (Husnurrosyidah \& Nuraini, 2016). A tax amnesty study on individual taxpayers in KPP Pratama Jakarta Kembangan also showed a positive and significant effect (Huslin \& Ngadiman, 2015), so did the researches in KPP Pratama of East Denpasar (Wirawan \& Noviari, 2017), KPP Pratama of Manado (Rorong, Kalangi, \& Runtu, 2017), KPP Pratama of Surabaya Tegalsari (Sari, 2017).

All previous studies have shown a positive and significant effect. However, those studies were conducted when the tax amnesty program was still ongoing. Therefore, it was deemed necessary to carry out a research on taxpayer compliance before and after the tax amnesty program in KPP Pratama of Jepara. Based on Law No. 11 of 2016, the amnesty program was conducted from July 1, 2016, to March 31, 2017. It is important to study the condition after the implementation of the program to find out whether the tax amnesty policy is able to affect taxpayer compliance. This study will be conducted in the working area of KPP Pratama of Jepara, Central Java, involving individual and corporate taxpayers. Jepara Regency became the research choice because it is a small town that is not passed by the pantura roads but has become a productive area with various home productions. Due to lack of socialization and information, it is very likely that the residents of Jepara are not well educated and informed about taxation. One research in 2012 showed that only $57 \%$ of the people in Jepara were aware that every taxpayer had an Account Representative (AR) when performing their tax obligations (Subadriyah, 2013).

\subsection{Research Problem}

a) How does taxpayer compliance before and after tax amnesty stimuly?

\subsection{Research Purpose}

To find out and examine the effect of tax amnesty program implementation in increasing taxpayer compliance.

\section{THEORETICAL FRAMEWORK AND HYPOTHESES DEVELOPMENT} 2.1 Taxes and Functions

Tax is one source of financing needed by the state to run the government. This tax collection has long existed - in the past the taxation was done through tribute collection based on the rules made by the kings/rulers without involving the taxpayers, unlike today where the rules are made both by the government and the people through their representatives (Wardoyo \& Subiyakto, 2016). Taxes are the contribution of the people to the state treasury under the law (which can be enforced) in the absence of returned services (contra) which can be directly demonstrated and used to pay public expenditures (Resmi, 2014). Based on the definition and function of tax in Indonesia, it indicates that the taxpayers can not directly benefit from taxes they pay to the state. This naturally makes people reluctant to perform their tax obligations. 


\subsection{Tax Amnesty}

According to the Indonesian tax amnesty law of 2016, tax amnesty is the elimination of payable taxes, which shall not be subject to any administrative sanction or criminal sanction, through asset disclosure and redemption payment. The purpose of tax amnesty is to increase the state's revenue and economic growth, as well as awareness and compliance among the people who have tax obligations. Taxpayers, both individuals, and corporates, who report and bring home their assets to Indonesia will not be penalized but only required to pay a certain amount of redemption money defined by the government. For taxpayers who do not participate in the tax amnesty program but are found to possess unreported net assets, those assets are treated as income upon discovery and will be subject to taxes and administrative penalty in accordance with tax regulations (Rahayu, 2017).

\subsection{Taxpayer Compliance}

Taxpayer compliance is the fulfillment of tax obligations voluntarily undertaken by taxpayers in order to contribute to the development of the State (Suyanto, Intansari, \& Endahjati, 2016). It is a condition when taxpayers meet all of their tax obligations and use their taxation rights. Furthermore, tax compliance is divided into two: 1) formal compliance and 2) material compliance. The formal tax compliance is the compliance regulated in accordance with the provisions in the tax law, for example having a Taxpayer Identification Number (NPWP) for those who already have income, reporting Periodic or Annual Tax Return before the deadline, and paying off the tax debt in accordance with the stipulated deadline. Meanwhile, the material tax compliance is a condition when the taxpayers substantively complied with all the provisions of taxation materials according to the contents of tax laws (Hutasoit, 2017).

\subsection{The Effect of Tax Amnesty Toward Taxpayer Compliance}

Bayer, Oberhofer, \& Winner (2015) revealed that based on data from the United States from 1981 to 2011, tax amnesty programs were followed with the hope of obtaining forgiveness as well as convenience in the future. The program is expected to increase taxpayer compliance and tax revenue through on-going supervision (Andreoni, 1991). Tax amnesty will succeed in improving taxpayer compliance in the future through socialization and tax-aware campaigns inadequate media (Santoso \& Setiawan, 2009). A research done in Bantul Regency in the Special Region of Yogyakarta showed the positive effect of tax amnesty on taxpayer compliance (Rahayu, 2017). This policy also positively affected the taxpayer compliance among the members of Islamic microfinance institution BMT (Baitul Mal Wat-Tamwil) in Pati Residency, Central Java (Husnurrosyidah \& Nuraini, 2016). A tax amnesty study on individual taxpayers in KPP Pratama Jakarta Kembangan also showed a positive and significant effect (Huslin \& Ngadiman, 2015), so did the researches in KPP Pratama of East Denpasar (Wirawan \& Noviari, 2017), KPP Pratama of Manado (Rorong, Kalangi, \& Runtu, 2017), KPP Pratama of Surabaya Tegalsari (Sari, 2017). Based on the above results, the hypotheses in this study are:

$\mathrm{H}_{1}$ : Tax Amnesty has a positive effect on taxpayer compliance before and after the program ends.

\section{RESEARCH METHOD}

\subsection{Research Design}

This is quantitative research that will analyze the difference of influence of tax amnesty policy toward taxpayer compliance and tax implementation before and after-tax amnesty program ends. Primary data was used in this study, which was obtained from a first party. The method of data collection was by distributing questionnaires to respondents using Likert scale measurement. 
The questionnaires consisted of questions or statements related to taxpayer compliance after the implementation of the tax amnesty program. The method of analysis used to prove the effect of tax amnesty on taxpayer compliance in Jepara before and after the tax amnesty ended was t-test analysis. The t-test method was paired sample t-test. The variables compared were taxpayer compliances before and after the tax amnesty. To make decisions, the data analysis was compared to table t. The selected significant value was $5 \%(0.05)$.

\subsection{Population dan Sample}

The population in this study were all individual and corporate taxpayers in the region of Jepara Regency, which included 52,512 people. The entire population was then narrowed down by calculating the sample size using the Slovin's formula, which resulted in a sample of 100 respondents. Samples were taken using purposive sampling technique. The selected sample was taxpayers who have already had Tax ID Numbers (NPWP) and joined this tax amnesty program.

\subsection{Research Framework}

The variables in this study consist of an independent variable and dependent variable. The independent variable is the Tax Amnesty. Tax Amnesty is the elimination of payable taxes, which shall not be subject to any administrative sanction or criminal sanction, through asset disclosure and redemption payment. While the dependent variable is taxpayer compliance. Tax compliance is a condition when the taxpayers meet all of their tax obligations and use their taxation rights. Tax compliance is classified into two: 1) formal tax compliance and 2) material tax compliance (Hutasoit, 2017).

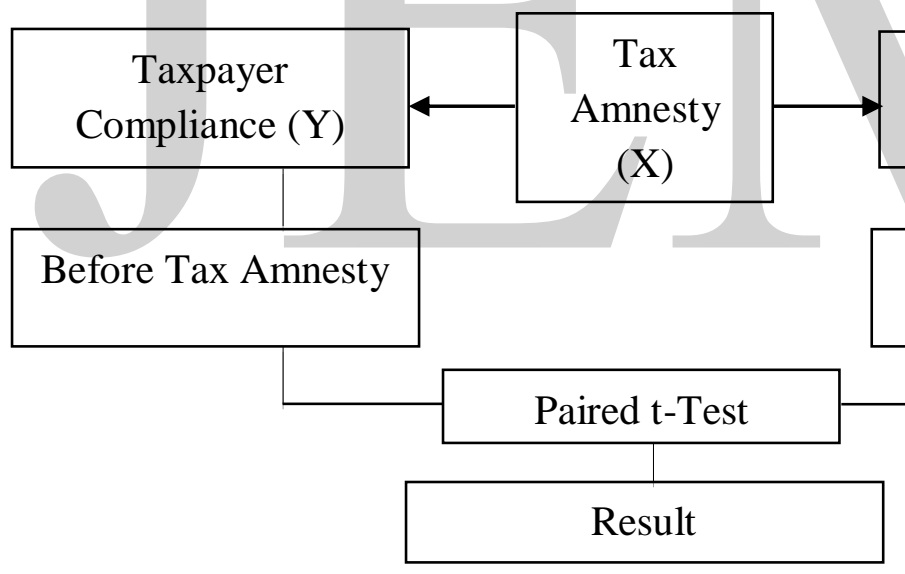

Picture 1 Research Framework

\section{RESEARCH RESULT AND ANALYSIS \\ 4.1 Descriptive Analysis}

The data of respondents' profiles in this study were described by demographic characteristics, including sex, age, occupation, education level and average monthly income (Table 1). The table shows that the number of male respondents is $6 \%$ higher than female respondents. This shows that the difference of NPWP ownership between men and women is not too big. Tax reforms have enabled working women to obtain Tax ID Numbers (NPWP). The age of the participating respondents varies, and there is no age group that dominates significantly. Most respondents were in the productive age group of 25 to 35 (38\%), while $36 \%$ of them were aged 35 to 45 . Of the 100 respondents, some of them were under the age of 25 (22 and 23). This shows that there is active 
participation from the community in fulfilling their obligation as good citizens by registering to get NPWPs, although the number was very small (2\%). Furthermore, based on the tax amnesty participation criteria, this table indicates that even those under the age of 25 were quite enthusiastic in complying with the existing tax regulations, as evidenced by their participation in the tax amnesty program (Table 2).

Table 1 Distribution of Respondent Characteristics (Sex)

\begin{tabular}{|l|c|c|}
\hline \multicolumn{1}{|c|}{ Sex } & Count & Percentage \\
\hline Male & 53 & $53 \%$ \\
\hline Female & 47 & $47 \%$ \\
\hline
\end{tabular}

Source: Primary Data Processed, 2018

Table 2 Distribution of Respondent Characteristics (Age)

\begin{tabular}{|l|c|c|}
\hline \multicolumn{1}{|c|}{ Ages } & Count & Percentage \\
\hline$<25$ years old & 2 & $2 \%$ \\
\hline 25-35 years old & 38 & $38 \%$ \\
\hline 35-45 years old & 36 & $36 \%$ \\
\hline 45-55 years old & 16 & $16 \%$ \\
\hline$>55$ years old & 8 & $8 \%$ \\
\hline
\end{tabular}

Source: Primary Data Processed, 2018

Meanwhile, based on the statistics of respondents' jobs (Table 3), most respondents in this study are private sector employees (42\%), with the majority working in textile factories, which are part of Foreign Investment (PMA) in Jepara. With the increasing number of PMAs recently established in Jepara, the number of taxpayers registered in the local KPP Pratama will increase too. This is because the PMAs require their employees to have NPWPs. The occupation ofthe second place of the list is entrepreneurs, which is $30 \%$. The rest of the list (23\%) includes doctors, nurses, grocery-shop owners, food stalls owners, and savings and loan cooperatives (KSP). There were 12 KSPs that joined the tax amnesty program. Cooperatives founded before 2012 are not required to have NPWPs. Therefore they welcomed this Tax Amnesty program as it reduced the amount of tax they did not pay in the past. In addition, this amnesty policy became an initial step for KSPs to report their tax obligations regularly. The level of education of the respondents in this study was dominated by High School and its equivalents (40\%). Based on the data of job type, it can be seen that most of the respondents were private sector employees who worked in Foreign Investment (PMA) companies that were mostly textile factories. High level of education is not a requirement to work in such factories, hence the high number of high school graduates. The next most popular levels of education were S1 (Bachelor's degree), diploma and S2 (Master's degree), which was owned by only 5 people. Most of the respondents earned an average monthly income of less than Rp. 4.5 million (Table 5). This was in line with the type of work they did, which was in the factories. However, the factory rules still require their employees to have NPWP. This is against the regulation of NPWP ownership obligations as stated in the Regulation of the Director General of Taxation No. PER-16 / PJ / 2016, PMK no. 101 / PMK.010 / 2016 and PMK No. 102 / PMK.010 / 2016 that the Non-Taxable Income (PTKP) for Individual Taxpayer is IDR 54,000,000 a year or IDR 4,500,000 a month. 
JEMA: Jurnal Ilmiah Bidang Akuntansi dan Manajemen, Vol. 15 No. 2 (2018)

http://riset.unisma.ac.id/index.php/jema (e-ISSN : 2597-4071)

Table 3 Distribution of Respondent Characteristics (Occupation)

\begin{tabular}{|l|c|c|}
\hline \multicolumn{1}{|c|}{ Occupation } & Count & Percentage \\
\hline Private Employee & 42 & $42 \%$ \\
\hline Civil Servant & 5 & $5 \%$ \\
\hline Entrepreneur & 30 & $30 \%$ \\
\hline Others & 23 & $23 \%$ \\
\hline
\end{tabular}

Source: Primary Data Processed, 2018

Table 4 Distribution of Respondent Characteristics (Education Level)

\begin{tabular}{|l|c|c|}
\hline \multicolumn{1}{|c|}{ Education Level } & Count & Percentage \\
\hline Senior High School & 40 & $40 \%$ \\
\hline Diploma & 24 & $24 \%$ \\
\hline Bachelor Degree & 31 & $31 \%$ \\
\hline Master Degree & 5 & $5 \%$ \\
\hline
\end{tabular}

Source: Primary Data Processed, 2018

Table 5 Distribution of Respondent Characteristics (Income)

\begin{tabular}{|l|c|c|}
\hline \multicolumn{1}{|c|}{ Income (IDR) } & Count & Percentage \\
\hline$<4.500 .000$ & 62 & $82 \%$ \\
\hline $4.500 .000-9.000 .000$ & 38 & $18 \%$ \\
\hline
\end{tabular}

Source: Primary Data Processed, 2018

Overall, the respondents who have filled out the questionnaires were mostly individual taxpayers. Only $20 \%$ of the respondents were corporate taxpayers, most of whom were furniture entrepreneurs in Jepara and savings and credit cooperatives (KSP).

\subsection{Validity and Reliability}

The validity test of the questionnaire was conducted in order to determine the validity of the questionnaire. All constructs of the question in this study can categorized as a valid and reliable because they significant in 0.05 ( $r$-value > r-table) and greater than 0.60 for Crobach Alpha rule.

\subsection{Research Analysis}

Before performing a t-test, the data were first tested using Kolmogrov-Smirnov nonparametric normality test $(\mathrm{K}-\mathrm{S})$ to determine whether or not the data before and after the tax amnesty program were normally distributed. In a normal test, if the sig value is $<\alpha$, then the data is not normally distributed, but if the sig value is $>\alpha$, then the data's distribution is considered normal, with the value of $\alpha=0,05(5 \%)$. Based on Normality Test table, it can be seen that the data before and after the tax amnesty program had a normal distribution with significance value higher than 0.05. This meant that the next test, which was a t-test, could be performed on the collected data. 
JEMA: Jurnal Ilmiah Bidang Akuntansi dan Manajemen, Vol. 15 No. 2 (2018)

http://riset.unisma.ac.id/index.php/jema (e-ISSN : 2597-4071)

Tabel 6 Normality Result

\begin{tabular}{|c|c|c|}
\hline Variables & Sig. & Conclusion \\
\hline Before (Pre-Test) Tax Amnesty & 0.072 & Normal \\
\hline After (Pro-Test) Tax Amnesty & 0.057 & Normal \\
\hline
\end{tabular}

Source: Primary Data Processed, 2018

\subsection{Research Discussion}

Table 7 Paired Sample t-Test Result

\begin{tabular}{|c|c|c|c|}
\hline Variables & Mean & Sig & Conclusion \\
\hline Before (Pre-Test) Tax Amnesty & 55,2000 & \multirow{2}{*}{0.006} & Significant \\
\cline { 1 - 2 } After (Pro-Test) Tax Amnesty & 56,0100 & & \\
\hline
\end{tabular}

Source: Primary Data Processed, 2018

The following is the summary of test results conducted to determine whether or not there is a difference of taxpayer compliance between before and after the tax amnesty program. Based on the T-Test table, it is known that the average value before the resulting amnesty tax had increased, with the significance value being $0.006(<0.05)$. This result indicates a significant difference between before and after tax amnesty, meaning that the program had a positive effect on taxpayer compliance before and after it ended. The pretest average value before tax amnesty was 55.2000 and the pro-test average value after tax amnesty was 56.0100. This shows that there was an increasing value between the two periods, which was $0.81(56.0100-55.2000)$. This difference is still considered very low, which means that the long-term goal of the amnesty tax to gain more valid, comprehensive, and integrated database extension has not been achieved. This was despite the asset disclosure in Indonesian being far superior compared to other countries who have implemented the same program, such as Italy (Rp59 trillion), Australia (Rp8 trillion), Chile (Rp20 trillion), and Spain (Rp18 trillion) (Pajak, 2016).

Tax amnesty is one of the programs to improve taxpayer compliance. When the taxpayers receive tax forgiveness, it is expected that their compliance in the future will increase. Implementation of this tax amnesty will have a positive impact on increasing the state's revenues and economic growth. With the increasing awareness and compliance of tax among the citizens, the long-term goal of tax amnesty, which is to expand the taxpayer database, will be achieved. Taxpayers who have never been part of the tax administration system will join the program and become part of the system. This will prevent taxpayers from avoiding their obligations in paying as well as reporting taxes, hence the increase of compliance. Knowing that tax amnesty program is a good opportunity that does not come regularly, taxpayers who have never reported their assets before will be encouraged to make use of it because they will get tax deductions. Tax amnesty is an opportunity for certain groups of taxpayers to pay a certain amount of redemption money for the tax liability from previous years. However, the results of this study show that the increase in taxpayer compliance was very little from before-tax amnesty, which was 0.81 . The success of a tax amnesty program in improving taxpayer compliance and increasing tax revenues strongly depends on various factors, especially ongoing supervision (Andreoni, 1991), socialization and tax-awareness campaigns through adequate media coverage (Santoso \& Setiawan, 2009). In 2018, one year after the implementation of a tax amnesty policy, the Indonesian Directorate General of Taxes is still investigating taxpayers who do not take advantage of this program. This shows that closer supervision to the tax amnesty program and participants is still required, although at least the 
amnesty program managed to improve the taxpayer database which could be used by the state to increase the future state revenue (Fatmala \& Ardini, 2017).

\section{RESEARCH CONCLUSION AND LIMITATION}

\subsection{Conclusion}

Based on the above discussion, it can be concluded that the tax amnesty has a positive effect on taxpayer compliance, both in the pre-test and pro-test periods after the end of the program. The significance value of less than 0.05 and an increase in the average value before the tax amnesty mean that taxpayers who participated in the program have higher a compliance. And those who have never reported their assets will become tax-conscious thanks to the tax amnesty that worked as a stimulus.

\subsection{Limitation}

This study was conducted only in Jepara regency, especially involving taxpayers registered at KPP Pratama Jepara, where the majority of those who filled the questionnaires were individual taxpayers, which became one of the limitations of this study.

\section{REFERENCES}

Andreoni, J. (1991). The Desirability of a Permanent Tax Amnesty. Journal of Public Economics, 45, 143-159. https://doi.org/10.1016/0047-2727(91)90037-3.

Ayu R, S. D., \& Hastuti, R. (2009). Persepsi Wajib Pajak: Dampak Pertentangan Diametral Pada Tax Evasion Wajib Pajak Dalam Aspek Kemungkinan Terdeteksinya Kecurangan, Keadilan, Ketepatan Pengalokasian, Teknologi Sistem Perpajakan, dan Kecenderungan Personal. (Studi Wajib Pajak Orang Pribadi. Jurnal Ilmiah Kajian Akuntansi, 1(1), 1-12.

Azwar, \& Mulyawan, A. W. (2017). Analisis Underground Economy Indonesia dan Potensi Penerimaan Pajak. Jurnal Info Artha, 1(1), 60-78. http://dx.doi.org/10.31092/jia.v1i1.18.

Bayer, R. C., Oberhofer, H., \& Winner, H. (2015). The Occurrence of Tax Amnesties: Theory and $\begin{array}{lllll}\text { Evidence. Journal of Public } & \text { Economics, }\end{array}$ https://doi.org/10.1016/j.jpubeco.2015.02.006

Dwijugiasteadi, K. (2016). Kontribusi Strategis Membangun Bangsa Melalui Amnesti Pajak. Jakarta.

Fatmala, N. D., \& Ardini, L. (2017). Persepsi Wajib Pajak Pada Program Tax Amnesty Untuk Meningkatkan Penerimaan Pajak. Jurnal Ilmu Dan Riset Akuntansi, 6(8).

Huslin, D., \& Ngadiman. (2015). Pengaruh Sunset Policy, Tax Amnesty, dan Sanksi Pajak Terhadap Kepatuhan Wajib Pajak (Studi Empiris di Kantor Pelayanan Pajak Pratama Jakarta Kembangan). Journal Tarumanegara, XIX(2), 225-241. Retrieved from http://journal.tarumanagara.ac.id/index.php/jakt/article/view/2292.

Husnurrosyidah, \& Nuraini, U. (2016). Pengaruh Tax Amnesty Dan Sanksi Pajak Terhadap Kepatuhan Wajib Pajak di BMT se-Karesidenan Pati. Equilibrium: Jurnal Ekonomi Syariah, 4(2), 211-226. http://dx.doi.org/10.21043/equilibrium.v4i2.1947.

Hutasoit, G. (2017). Pengaruh Tax Amnesty Terhadap Kepatuhan Wajib Pajak di Kota Palembang. Seminar Nasional Teknologi Informasi, Bisnis, Dan Desain. Retrieved from 
http://jurnal.syntaxliterate.co.id/index.php/syntax-literate/article/view/90/147.

Ismi, S. (2017). Tax Amnesty dan Pengaruhnya Terhadap Tax Compliance. Retrieved from https://www.kemenkeu.go.id/publikasi/artikel-dan-opini/tax-amnesty-dan-pengaruhnyaterhadap-tax-compliance/.

Lerman, A. H. (1986). Tax Amnesty; The Federal Perspective. The National Tax Journal, 39(3), 325-332. https://doi.org/0028-0283.

Pajak, D. J. (2016). Laporan Keuangan Audited 2016. Jakarta.

Rahayu, N. (2017). Pengaruh Pengetahuan Perpajakan, Ketegasan Sanksi Pajak, dan Tax Amnesty Terhadap Kepatuhan Wajib Pajak. Akuntansi Dewantara, 1(1), 15-30. http://dx.doi.org/10.29230/ad.v1i1.21.

Resmi, Si. (2014). Perpajakan Teori dan Kasus (8th ed.). Jakarta: Salemba Empat.

Rorong, E. N., Kalangi, L., \& Runtu, T. (2017). Pengaruh Kebijakan Tax Amnesty, Kesadaran Wajib Pajak dan Sanksi Pajak Terhadap Kepatuhan Wajib Pajak Orang Pribadi di KPP Pratama Manado. Jurnal Riset Akuntansi Going Concern, 12(2), 175-187.

Santoso, U., \& Setiawan, J. M. (2009). Tax Amnesty and Its Implementation in Some Countries, Indonesian Entrepreneurs Perspective. Sosiohumaniora, 11(2), 111-125.

Sari, V. A. P. (2017). Pengaruh Tax Amnesty, Pengetahuan Perpajakan, Dan Pelayanan Fiskus Terhadap Kepatuhan Wajib Pajak. Jurnal Ilmu Dan Riset Akuntansi, 6(2).

Subadriyah. (2013). Pengaruh Moderasi Tax Morale Terhadap Hubungan Variabel Sosio Demografi dan Tax Avoidance Pajak Penghasilan di KPP Pratama Jepara. Jurnal Dinamika Eko, 10(2), 194-203.

Suyanto, Intansari, P. P. L. A., \& Endahjati, S. (2016). Tax Amnesty. Jurnal Akuntansi Fakultas Ekonomi Universitas Sarjanawiyata Tamansiswa, $\quad 4(2), \quad 9-22$. https://doi.org/10.24964/ja.v4i2.217.

Wardoyo, T. H., \& Subiyakto, A. (2016). Taxation: Pengantar Perpajakan Indonesia. Tangerang Selatan: Taxsys.

Wirawan, I. B. A. P., \& Noviari, N. (2017). Pengaruh Penerapan Kebijakan Tax Amnesty dan Sanksi Perpajakan Terhadap Kepatuhan Wajib Pajak Orang Pribadi. E-Jurnal Akuntansi Universitas Udayana, 21(3), 2165-2194. https://doi.org/https://doi.org/10.24843/EJA.2017.v21.i03.p17

*) Subadriyah, Department of Accounting, University of Islam Nahdlatul Ulama, Jepara, Indonesia (Email : subadriyah@unisnu.ac.id)

**) Siti Aliyah, Department of Accounting, University of Islam Nahdlatul Ulama, Jepara, Indonesia (Email : staliyah10@gmail.com) 